\title{
PHYSICAL AND MECHANICAL PROPERTIES OF GARLIC RELATING RUBBING AND PLANTING MACHINES
}

\author{
A. M. DRESS ${ }^{(1)}$
}

\section{ABSTRACT}

This study was conducted to investigate physical, mechanical and chemical properties of Garlic white (Allium sativum L.) for bulb and clove. The considered parameters were length, width, thickness, mass , volume, solid density, bulk density, porosity, Arithmetic mean diameter, Geometric mean diameter, sphericity, packaging coefficient, Surface area, projected area, coefficient of static friction with different surfaces (wood, glass, rubber, steel, fiber, plastic), angle of repose (empty, filling), rubbing force and rupture force.

The average values of properties, measured at a moisture content of $12.97 \pm 0.30 \%$ (dry basis): for garlic bulb, length, width, thickness, mass , volume, solid density, bulk density, porosity, arithmetic mean diameter, geometric mean diameter, sphericity, packaging coefficient, surface area and projected area, were $59.9 \mathrm{~mm}, 58 \mathrm{~mm}, 45.2 \mathrm{~mm}, 62.5 \mathrm{~g}$, and 103.5 $\mathrm{cm}^{3}, 0.61 \mathrm{~g} / \mathrm{cm}^{3}, 0.45 \mathrm{~g} / \mathrm{cm}^{3}, 25.9 \%, 54.4 \mathrm{~mm}, 53.85 \mathrm{~mm}, 0.90,0.97$, $91.4 \mathrm{~cm}^{2}$ and $(50.05 / 42.27) \mathrm{cm}^{2}$ respectively. The same value for garlic clove were $26.4 \mathrm{~mm}, 11.9 \mathrm{~mm}, 8.5 \mathrm{~mm}, 1.49 \mathrm{~g}$, and $4.39 \mathrm{~cm}^{3}, 0.94 \mathrm{~g} / \mathrm{cm}^{3}$, $0.57 \mathrm{~g} / \mathrm{cm}^{3}, 39.6 \%, 15.6 \mathrm{~mm}, 13.7 \mathrm{~mm}, 0.53,0.46,6.1 \mathrm{~cm}^{2}$ and (2.66/0.5) $\mathrm{cm}^{2}$ respectively.

The coefficient of static friction of bulb and clove on various surfaces showed that static friction on rubber is higher then on other surfaces and static friction on fiber is the lowest. Angle of repose of bulb and clove were higher when applying the filling method than when applying the empting method. It was also noticed that angle of repose of clove for both methods was higher than for bulb. The rubbing force ranged from 8.99 to $14.5 \mathrm{~kg}$. While the rupture force of the clove ranged from 2.5 to $13.54 \mathrm{~kg}$.

Keywords: Garlic, Physical properties, Mechanical properties, Coefficient of friction, Angle of repose, Rubbing force and Rupture force.

(1) Assist. Prof., Ag. Eng. Dept., Fac. of Agric., AL-Azhar University- Assuit. 


\section{INTRODUCTION}

arlic is one of the most important crops in Libya and moreover
is one of the worlds first important vegatable crops. Garlic
(Allium sativum $L$.) has been cultivated since ancient times all over the world especially in Asia. Garlic has medicinal properties and it is an important ingredient of the most exotic cuisine around the world. Garlic as a spice is utilized in both fresh and dehydrated state in the food industry. It is dehydrated into different products such as flakes, slices, and powders (Ahmad, 1996).

Garlic does not produce seeds, so it must be propagated vegetatively with garlic cloves as the most common planting material. The yield quality of garlic is affected by planting methods and clove rates and sizes (Nourai, 1994; Matlob and Khalel, 1986).

Lack of data about basic engineering properties of this planting material is a problem identified in the development of new methods of sowing the garlic crop, development of new equipment for processing and control strategies for crop storage.

Madamba et al. (1993) measured the length, width, and thickness of garlic slices by using vernier caliper. Song and Litchfield, (1991) measured the length and width of seed grains by using a computer imaging system while using a caliper to measure the third dimension. Tabil et al. (1999) used an image analysis program to determine the size and shape characteristics of some specialty crops such as chickpeas, lentils and peas including the length of the longest and shortest axes, cross section area, perimeter of the object, circularity and roundness of each seed. Olaoye (2000) used an overhead projector to project the image of the nut samples on a plain cardboard sheet to characterize the shape. Sizes of materials usually play a significant role under approximately the same operating conditions (Gupta and Das, 1997), as shown by Marijana (1996) who investigated the effects of the size of cloves on the yield of garlic. Gupta and Das (1997) reported a correlation among various dimensions of sunflower seeds.

The influence of moisture content on several physical properties was reported by some researchers (Madamba et al., 1994; Joshi et al., 1993). Kaleem et al. 
(1993) mentioned that the angle of repose is very important in determining the inclination angle of the machine hopper tank. Mohsenin, (1986) clarified that the knowledge of the surface area of vegetables and fruits is important in many aspects like heat transfer studies in heating and cooling processes.

Some researchers (Mohsenin, 1986; Zhang et al. 1994) investigated the reasons of variation in the coefficient of friction values of biological materials. The experimental results showed that sliding surface, moisture content, velocity, normal pressure, temperature, humidity and testing technique affected friction values. Therefore, specific conditions should be considered while determining the coefficient of friction values of agricultural products.

Zhang et al. (1994) used a Wykeham Farrace shear box apparatus to determine grain friction of wheat. Chandrasekar and Viswanathan (1999); Olajide and Ade-Omowaye (1999) used an inclined surfaces to measure coefficient of friction of material. Schaper and Yaeger (1992) used an instron to measure the frictional force between material and surfaces. A rotary disk was used to measure static and dynamic coefficient of frictions of chickpea seeds (Konak et al. 2002).

The objective of this study was to determine some the physical and mechanical properties of garlic cloves and bulb including length, width, thickness, mass, volume, solid density, bulk density, porosity, Arithmetic mean diameter, geometric mean diameter, sphericity, packaging coefficient, surface area, projected area, coefficient of static friction, angle of repose, rubbing force and rupture force.

\section{MATERIAL AND METHODS}

\subsection{Sample Preparation}

Garlic bulbs (White) were obtained locally in the region of Al-Bayda, Libya. Freshly harvested garlic bulbs were randomly collected from different farms. Similar to local practice, the bulbs were dried by spreading in a thin-layer inside a darkroom with open windows near the farms for 15 days. Samples were stored in cool room at $5^{\circ} \mathrm{C}$. The sample bulbs were randomly selected from the bulk sample and the outer shell was manually peeled before experiments. The moisture content of cloves was determined by following ASAE S352.2 (ASAE 1999) standard. 
Each sample weighing about $10 \mathrm{~g}$, were placed in a convection oven set at $130^{\circ} \mathrm{C}$ for $50 \mathrm{~min}$. The samples were, weighed and the moisture content was calculated and expressed in percent dry basis (d.b.).

\subsection{Physical properties}

\subsubsection{Dimensions}

The fruit size, in terms of the three principal axial dimensions, that is (in $\mathrm{mm}$ ): length, L, width, W, and thickness, $\mathrm{T}$, was measured using a vernier

caliper (Mitutoyo, Japan) with an accuracy of $0.01 \mathrm{~mm}$. Figure (1) shows the three dimension of bulb and clove of garlic.

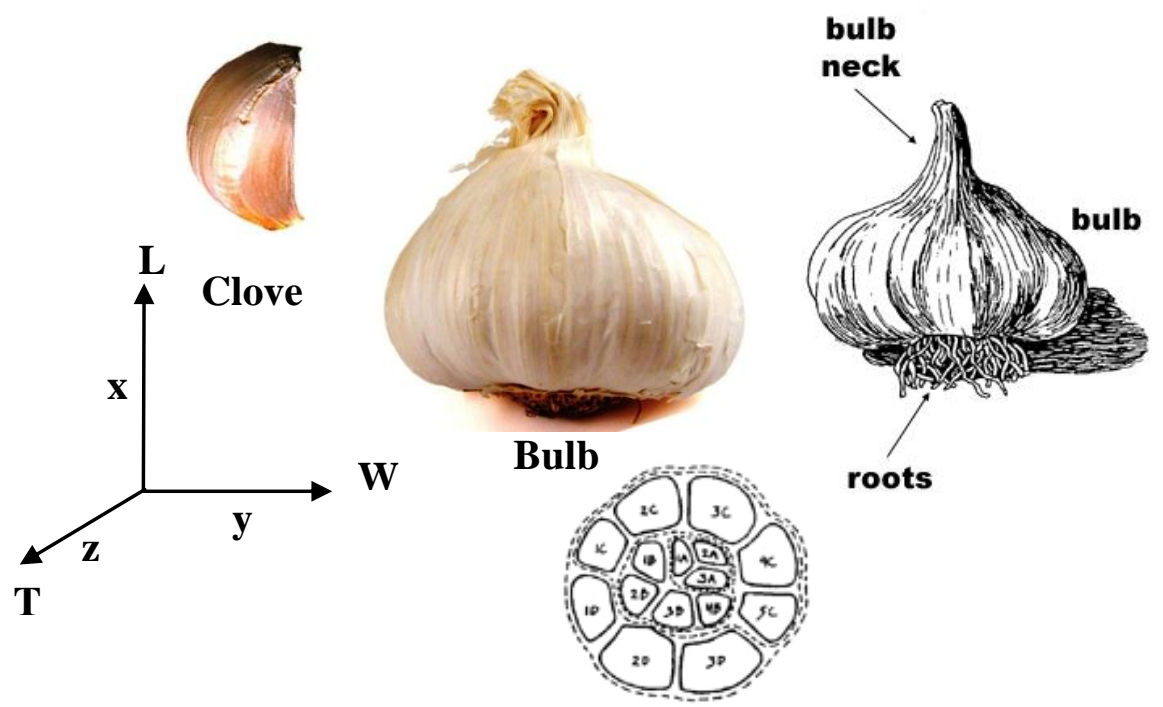

Figure (1): The three major dimensions of clove and bulb garlic, where $\mathrm{x}$-axis is length (L), $\mathrm{y}$-axis is width $(\mathrm{W})$ and $\mathrm{z}$-axis is thickness $(\mathrm{T})$.

\subsubsection{Mass}

The unit mass, $\mathrm{m}(\mathrm{g})$ was recorded by using an experimental digital balance (Japan) with accuracy of $\pm 0.01 \mathrm{~g}$.

\subsubsection{Volume}

In order to determine fruit volume, a water containing container was placed on the balance, one needle was thrust in the fruit and one lever moved the needle, so that the fruit floated in water and the mass of displaced water was calculated. 


$$
\text { Volume }\left(\mathrm{cm}^{3}\right)=\frac{\text { Displaced water }(\mathrm{gm})}{\text { Water specific mass }\left(\mathrm{gm} / \mathrm{cm}^{3}\right)}
$$

Also, the volume of water displaced as a result of development of fruit is equal to the size of the fruit.

\subsubsection{Arithmetic mean diameter and geometric mean diameter}

The arithmetic mean diameter, $\mathrm{D}_{\mathrm{a}}$ and geometric mean diameter, $\mathrm{D}_{\mathrm{g}}$ of clove and bulb were calculated from the geometrical dimensions as (Mohsenin, 1986; Bahnasawy, 2007):

$$
\begin{gathered}
D a=\frac{(L+W+T)}{3} \\
D g=\sqrt[3]{L W T}
\end{gathered}
$$

Where

Da : Arithmetic mean diameter.

Dg : Geometric mean diameter.

$\mathrm{L}, \mathrm{W}, \mathrm{T}$ : Length, width and Thickness of bulb or clove of garlic respectively.

\subsubsection{Sphericity}

Sphericity of clove or bulb was calculated based on the isoperimetric property of a sphere (Mohsenin, 1986):

$$
\mathbf{S}_{\mathbf{p h}}=\frac{\mathbf{D g}}{\mathbf{L}}
$$

Where

$\mathrm{S}_{\mathrm{ph}} \quad$ : Sphericity.

\subsubsection{Bulk and solid density}

The bulk density is the ratio of the mass of the sample to its container volume. It was measured by weighing a filled measuring cylinder with known volume and calculated according to (Mohsenin, 1986):

$$
\rho_{b}=\frac{\mathbf{M}}{\mathbf{V}}
$$


Where

$\rho_{b} \quad: \quad$ Bulk density $\left(\mathrm{g} / \mathrm{cm}^{3}\right)$.

M : Mass of sample (g).

$\mathrm{V}$ : Volume of the sample container $\left(\mathrm{cm}^{3}\right)$.

The solid density or true density is defined as the ratio of mass of the sample to its true volume (Mohsenin, 1986; Joshi et al., 1993)

$$
\rho_{s}=\frac{\mathbf{M}}{\mathbf{V}_{\mathbf{c}}}
$$

Where

$\rho_{s} \quad: \quad$ Solid density $\left(\mathrm{g} / \mathrm{cm}^{3}\right)$.

M : Mass of samples (g).

$\mathrm{V}_{\mathrm{c}}$ : Volume of box that contains the samples $\left(\mathrm{cm}^{3}\right)$.

\subsection{7. porosity}

Porosity indicates the amount of pores in the bulk material and was calculated as (Mohsenin, 1986):

$$
\varepsilon=\left[1-\frac{\rho_{b}}{\rho_{s}}\right] .100
$$

Where

$\varepsilon \quad$ : Porosity (\%).

\subsubsection{Coefficient of packaging}

The Coefficient of packaging was computed (Topuz et al., 2005) as:

$$
\mathrm{R}_{\mathrm{a}}=\frac{\mathrm{W}}{\mathrm{L}}
$$

Where

$\mathrm{R}_{\mathrm{a}}$ : Coefficient of packaging.

\subsubsection{Surface area}

The surface area of bulk sample (fruit and kernel) was found by analogy with a sphere of the same geometric mean diameter, using the following relationship (Altunta ${ }^{o}$ et al., 2005): 


$$
\mathbf{S}=\pi \times \mathbf{D g}^{2}
$$

Where

$\mathrm{S} \quad$ : Surface area $\left(\mathrm{cm}^{2}\right)$.

Dg : geometric mean diameter $(\mathrm{cm})$.

\subsubsection{Projected area}

Projected areas were determined by image processing method. In order to obtain projected area, Scanner (Hp Deskjet F-2280) was used to make captured images for projected area of the fruit. Captured images deal with computer software program (AutoCAD) to calculate the area. Two major projected areas of apple fruit were determined at two areas (L-W) and $(\mathrm{W}-\mathrm{T})$.

\subsection{Mechanical properties of clove and bulb garlic}

\subsubsection{Coefficient of static friction}

Coefficient of static friction is the ratio of force required to start sliding the sample over a surface divided by the normal force, i.e. the weight of the object (Bahnasawy, 2007). The static coefficient of friction of clove and bulb garlic against different materials, namely plywood, fiber glass, plastic, glass, steel and rubber was determined.

A device was designed and fabricated, and used for the determination of the coefficient. The device shown in figure (2) mainly consists of: two open sides cylinder threaded from its outer side, to adjust it up and down, by a nut resting on a carriage surface. The carriage had a horizontal plate surface $275 \times 120 \times 20 \mathrm{~mm}$ and fixed to three roll bearing wheels, one in the front and 2 in the back to support the carriage. Under this design, the cylinder down open side could be adjusted to be very close to a third part which is a metallic surface made of steel $50(200 \mathrm{~mm}$ wide, $350 \mathrm{~mm}$ length and $10 \mathrm{~mm}$ thickness), but without touching it. The two open sides cylinder is partially filled with the tested sample of the materials. The material is loaded by a cylindrical rod (a piston), $40 \mathrm{~mm}$ in diameter and $70 \mathrm{~mm}$ in depth (according to Ibrahim, 2008). The carriage is connected through a pivoting point to a $250 \mathrm{~N}$ load measuring transducer. The transducers cell is attached to a digital force gauge (Japanese made) to measure the needed pulling force to move the carriage to oppose the 
dynamic friction force between the sample and steel surface to maintain the motion. Figure (2) shows this designed device. This locally designed and fabricated device was used to measure the dynamic friction force between feed material and the friction surface (steel 50).
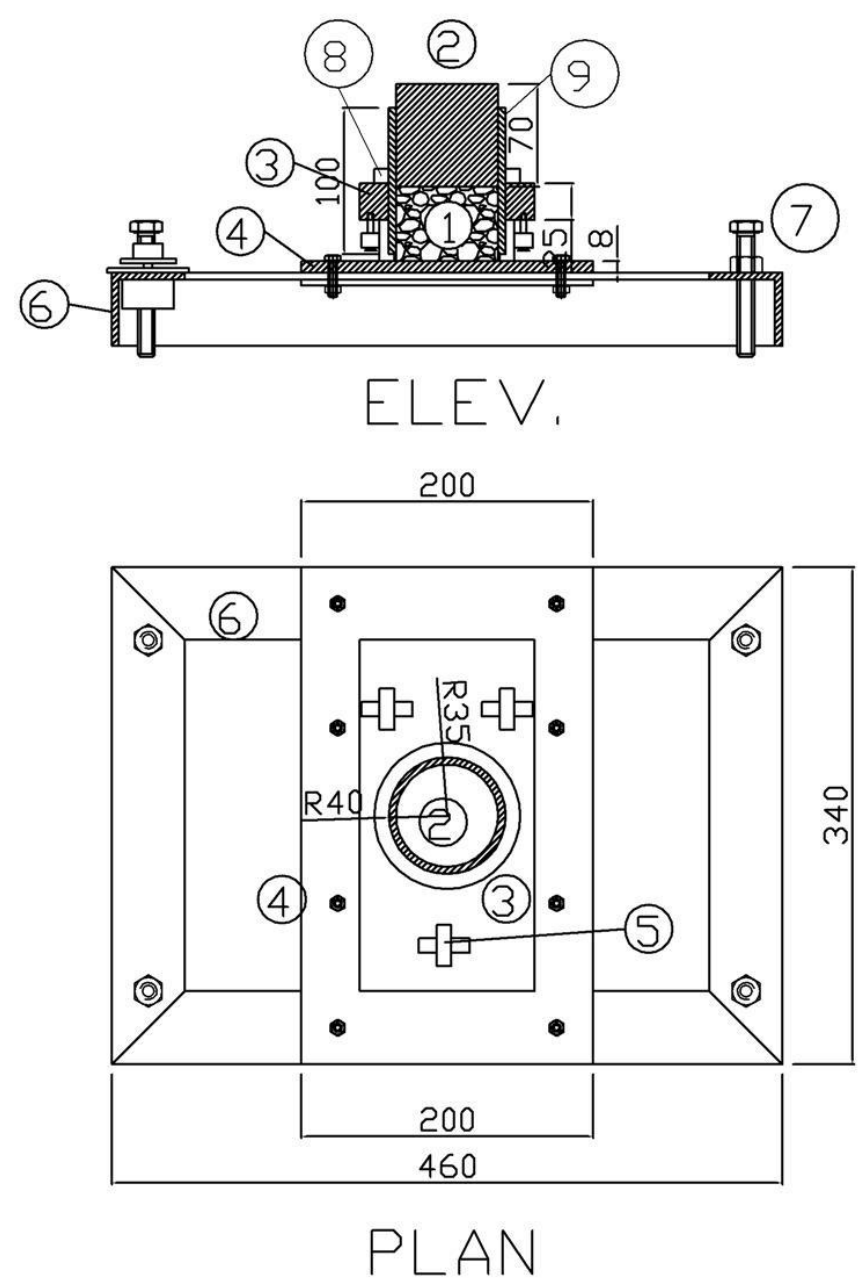

Dims. in mm
1-Sample
2- Piston
3- Carriage
4- Sliding surface
5- Rolling wheels
6- Base
7- Adjustable screw
8- Adjustable nut
9- Cylinder

Figure (2): The designed device for measuring the friction force. 
The static coefficient of friction was calculated as follows:

$$
\mu=\frac{F_{T}-F_{E}}{W}
$$

Where

$\mu \quad$ : Coefficient of static friction.

$\mathrm{F}_{\mathrm{T}} \quad: \quad$ Force required to start motion of filled wooden frame $(\mathrm{N})$.

$\mathrm{F}_{\mathrm{T}} \quad$ : Force required to start motion of empty wooden frame $(\mathrm{N})$.

W : Weight of the object $(\mathrm{N})$.

\subsubsection{Angle of repose}

The angle of repose indicates the cohesion among the individual units of a material. The higher the cohesion, higher is the angle of repose. The angle of repose of clove and bulb garlic was measured in two ways: (i) the filling method, to determine the static angle of repose and (ii) the emptying method, to determine the dynamic angle of repose.

For the filling method, a Hele-Shaw cell was built (Schlumberger, 2008). The sample was poured onto the cell through a fixed hopper in order to foster a constant feeding rate and thus the formation of a natural slope. The slope angle, namely static angle of repose was read with a protractor.

The emptying method was determined by using an open-ended cylinder of $15 \mathrm{~cm}$ diameter and $50 \mathrm{~cm}$ height. The cylinder was placed at the centre of a circular plate having a diameter of $70 \mathrm{~cm}$ and filled with fruit or kernel. The cylinder was raised slowly until it formed a cone on the circular plate. The height of the cone was recorded by using a movable pointer fixed on a stand having a scale of $0-1 \mathrm{~cm}$ precision. The angle of repose, was calculated using the formula (Karababa, 2006):

$$
\theta=\tan ^{-1}\left(\frac{2 H}{d}\right)
$$

Where:

$\theta \quad: \quad$ Angle of repose (empty or filling). 
$\mathrm{H} \quad$ : Height of the cone $(\mathrm{cm})$.

d : Diameter of cone $(\mathrm{cm})$.

\subsubsection{Rupture force and Rubbing force}

Laboratory compression tests were carried out by using a compression tester (Tokyo Japan) as shown in figure (3). Twenty units of garlic bulb or garlic clove were tested in length (L), width (W) and thickness (T) (Olaniyan and Oje, 2002).

The rupture force is the minimum force required to break the sample. While the rubbing force is the minimum force required to rub the bulb. The rupture force was measured with garlic clove, while the rubbing force was measured with garlic bulb.

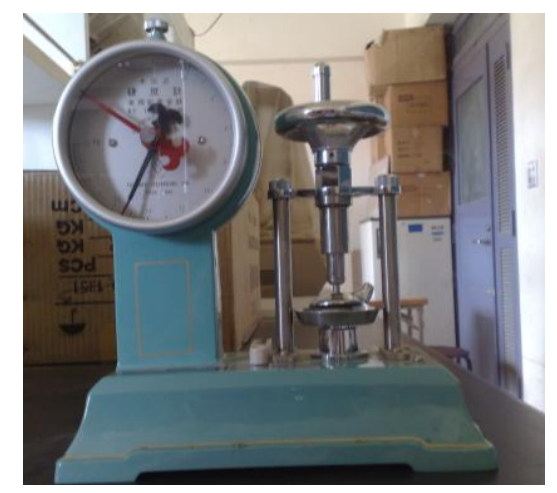

Figure (3): Compression tester.

\section{RESULTS AND DISCUSSION}

A summary of the results for all parameters measured and determined is shown in Table 1. The moisture content at the time of experiment was $12.97 \pm 0.30 \%$ dry basis.

\subsection{Physical property}

\subsubsection{Dimensions}

For the garlic bulb: Length (L) ranged from 53.3 to $73 .^{\circ} \mathrm{mm}$ with the mean value of $59.9 \pm 4.8 \mathrm{~mm}$ (Table 1). The width $(\mathrm{W})$ ranged from 51.6 to $67.2 \mathrm{~mm}$ with the mean value of $58 \pm 4.9 \mathrm{~mm}$. The thickness (T) ranged from 39.6 to $51.5 \mathrm{~mm}$ with the mean value of $45.2 \pm 3.7 \mathrm{~mm}$. 
For the garlic clove: Length (L) ranged from 13.9 to $36.6 \mathrm{~mm}$ with the mean value of $26.4 \pm 4.7 \mathrm{~mm}$. The width (W) ranged from 6 to $20 \mathrm{~mm}$ with the mean value of $11.9 \pm 3.4 \mathrm{~mm}$. The thickness $(\mathrm{T})$ ranged from 4.1 to $13.5 \mathrm{~mm}$ with the mean value of $8.5 \pm 2.2 \mathrm{~mm}$.

\subsubsection{Mass, volume, solid density and bulk density}

For the garlic bulb: mass ranged from 45.3 to $87.6 \mathrm{~g}$ with the mean value of $62.5 \pm 11.6 \mathrm{~g}$. The volume ranged from 61.3 to $133.6 \mathrm{~cm}^{3}$ with the mean value of $103.5 \pm 19.5 \mathrm{~cm} 3$. The solid density ranged from 0.45 to $0.86 \mathrm{~g} / \mathrm{cm}^{3}$ with the mean value of $0.61 \pm 0.11 \mathrm{~g} / \mathrm{cm}^{3}$. The bulk density ranged from 0.4 to $0.55 \mathrm{~g} / \mathrm{cm}^{3}$ with the mean value of $0.45 \pm 0.25 \mathrm{~g} / \mathrm{cm}^{3}$.

For the garlic clove: mass ranged from 0.24 to $5.2 \mathrm{~g}$ with the mean value of $1.49 \pm 0.98 \mathrm{~g}$. The volume ranged from 2.12 to $6.19 \mathrm{~cm}^{3}$ with the mean value of $4.39 \pm 0.13 \mathrm{~cm} 3$. The solid density ranged from 0.56 to $1.01 \mathrm{~g} / \mathrm{cm}^{3}$ with the mean value of $0.94 \pm 0.85 \mathrm{~g} / \mathrm{cm}^{3}$. The bulk density ranged from 0.45 to $0.61 \mathrm{~g} / \mathrm{cm}^{3}$ with the mean value of $0.57 \pm 0.19 \mathrm{~g} / \mathrm{cm}^{3}$.

\subsubsection{Porosity, Arithmetic mean diameter, Geometric mean diameter, Sphericity and Packaging coefficient}

For the garlic bulb: Porosity ranged from 10.1 to $48.4 \%$ with the mean value of $25.9 \pm 11.5 \%$. The arithmetic mean diameter ranged from 49.5 to $60.6 \mathrm{~mm}$ with the mean value of $54.4 \pm 3.2 \mathrm{~mm}$. The Geometric mean diameter ranged from 48.92 to $59.31 \mathrm{~mm}$ with the mean value of $53.85 \pm$ $3.15 \mathrm{~mm}$. Sphericity ranged from 1.1 to 1.3 with the mean value of $1.2 \pm$ 0.1 . Packaging coefficient ranged from 0.84 to 1.2 with the mean value of $0.97 \pm 0.1$.

For the garlic clove: Porosity ranged from 19.64 to $60.39 \%$ with the mean value of $39.36 \pm 3.7 \%$. The arithmetic mean diameter ranged from 9.4 to $22.3 \mathrm{~mm}$ with the mean value of $15.6 \pm 2.6 \mathrm{~mm}$. The Geometric mean diameter ranged from 7.6 to $20.6 \mathrm{~mm}$ with the mean value of 13.7 $\pm 2.6 \mathrm{~mm}$. Sphericity ranged from 0.36 to 1.05 with the mean value of $0.53 \pm 0.11$. Packaging coefficient ranged from 0.23 to 1.18 with the mean value of $0.46 \pm 0.14$.

\subsubsection{Surface area and projected area}


For the garlic bulb: Surface area ranged from 75.2 to $110.5 \mathrm{~cm}^{2}$ with the mean value of $91.4 \pm 10.7 \mathrm{~cm}^{2}$. The Projected area (major) ranged from 40 to $77.07 \mathrm{~cm}^{2}$ with the mean value of $50.05 \pm 8.98 \mathrm{~cm}^{2}$. The Projected area (minor) ranged from 35.7 to $50.5 \mathrm{~cm} 2$ with the mean value of 42.27 $\pm 4.4 \mathrm{~cm}^{2}$.

For the garlic clove: Surface area ranged from 1.8 to $13.3 \mathrm{~cm}^{2}$ with the mean value of $6.1 \pm 2.4 \mathrm{~cm} 2$. The Projected area (major) ranged from 2.36 to $3.28 \mathrm{~cm}^{2}$ with the mean value of $2.66 \pm 0.36 \mathrm{~cm}^{2}$. The Projected area (minor) ranged from 0.32 to $0.6 \mathrm{~cm}^{2}$ with the mean value of $0.5 \pm$ $0.14 \mathrm{~cm}^{2}$.

\subsection{Mechanical properties}

The static coefficient of friction varied on six different surfaces, with the garlic bulb from 0.20 to 0.61 with the mean value of $0.3 \pm 0.1$ on wood, from 0.02 to 0.07 with the mean value of $0.05 \pm 0.06$ on glass, from 0.20 to 0.5 with the mean value of $0.3 \pm 0.09$ on rubber, from 0.12 to 0.33 with the mean value of $0.2 \pm 0.08$ on steel, from 0.01 to 0.06 with the mean value of $0.03 \pm 0.02$ on fiber glass and from 0.07 to 0.15 with the mean value of $0.09 \pm 0.01$ on plastic. With the garlic clove, static coefficient of friction ranged from 0.3 to 0.69 with the mean value of $0.35 \pm 0.14$ on wood, from 0.1 to 0.21 with the mean value of $0.15 \pm 0.02$ on glass, from 0.25 to 0.52 with the mean value of $0.34 \pm 0.16$ on rubber, from 0.09 to 0.25 with the mean value of $0.1 \pm 0.07$ on steel, from 0.08 to 0.12 with the mean value of $0.13 \pm 0.03$ on fiber glass and from 0.1 to 0.21 with the mean value of $0.15 \pm 0.02$ on plastic.

Coefficient of static friction of bulb and clove on various surfaces showed that static friction on rubber is higher than on other surfaces and static friction on fiber is the lowest. The importance of studying friction coefficient depends two important things: first is to try to reduce the coefficient of friction in certain parts of the machine, and the second is the attempt to increase the coefficient of friction, especially in a rubbing process.

Angle of repose of bulb and clove is presented in Table (1).With garlic bulb, angle of repose (empty /filling) ranged from (25/26) to (28.5/30.5) with the mean value of $(27.5 \pm 1.01 / 28.5 \pm 2.05)$. With garlic clove, angle of repose (empty /filling) ranged from (34/36.5) to (39.5/41) with 
the mean value of $(36.5 \pm 1.2 / 38.7 \pm 1.12)$. The values were higher when applying the filling method than the empting method.

Table (1): Some physical and mechanical properties of garlic.

\begin{tabular}{|c|c|c|c|c|c|c|c|c|c|c|c|}
\hline \multirow{2}{*}{\multicolumn{2}{|c|}{ Property }} & \multicolumn{5}{|c|}{ Bulb } & \multicolumn{5}{|c|}{ Clove } \\
\hline & & $\dot{\mathbf{z}}$ & $\stackrel{\dot{x}}{\Sigma}$ & $\dot{\Xi}$ & 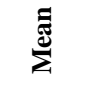 & 峁 & $\dot{\mathbf{z}}$ & $\stackrel{\dot{x}}{\Sigma}$ & $\dot{\Xi}$ & $\sum^{\mathbb{E}}$ & 宠 \\
\hline \multicolumn{12}{|c|}{ Physical property } \\
\hline \multicolumn{2}{|c|}{ L(length),mm } & 20 & $73.0^{\circ}$ & 53.3 & 59.9 & 4.8 & 100 & 36.6 & 13.9 & 26.4 & 4.7 \\
\hline \multicolumn{2}{|c|}{ W (width), mm } & 20 & 67.2 & 51.6 & 58.0 & 4.9 & 100 & 20.0 & 6.0 & 11.9 & 3.4 \\
\hline \multicolumn{2}{|c|}{ T (thickness), mm } & 20 & 51.5 & 39.6 & 45.2 & 3.7 & 100 & 13.5 & 4.1 & 8.5 & 2.2 \\
\hline \multicolumn{2}{|c|}{ Mass, $\mathrm{g}$} & 20 & 87.6 & 45.3 & 62.5 & 11.6 & 100 & 5.20 & 0.24 & 1.49 & 0.98 \\
\hline \multicolumn{2}{|c|}{ Volume, cm $^{3}$} & 20 & 133.6 & 61.3 & 103.5 & 19.5 & 100 & 6.19 & 2.12 & 4.39 & 0.13 \\
\hline \multicolumn{2}{|c|}{ solid density, g/cm ${ }^{3}$} & 20 & 0.86 & 0.45 & 0.61 & 0.11 & 100 & 1.01 & 0.56 & 0.94 & 0.85 \\
\hline \multicolumn{2}{|c|}{ Bulk density, g/cm } & 20 & 0.55 & 0.4 & 0.45 & 0.25 & 100 & 0.61 & 0.45 & $0.5 \vee$ & 0.19 \\
\hline \multicolumn{2}{|c|}{ Porosity, \% } & 20 & 48.4 & 10.1 & 25.9 & 11.5 & 100 & 60.39 & 19.64 & 39.36 & 3.7 \\
\hline \multicolumn{2}{|c|}{$\begin{array}{l}\text { Arithmetic mean } \\
\text { diameter, } \mathbf{m m}\end{array}$} & 20 & 60.6 & 49.5 & 54.4 & 3.2 & 100 & 22.3 & 9.4 & 15.6 & 2.6 \\
\hline \multicolumn{2}{|c|}{$\begin{array}{l}\text { Geometric mean } \\
\text { diameter, } \mathbf{m m}\end{array}$} & 20 & 59.31 & 48.92 & 53.85 & 3.15 & 100 & 20.6 & 7.6 & 13.7 & 2.6 \\
\hline \multicolumn{2}{|c|}{ Sphericity } & 20 & 1.01 & 0.81 & 0.90 & 0.05 & 100 & 1.05 & 0.36 & 0.53 & 0.11 \\
\hline \multicolumn{2}{|c|}{ Packaging coeff. } & 20 & 1.20 & 0.84 & 0.97 & 0.10 & 100 & 1.18 & 0.23 & 0.46 & 0.14 \\
\hline \multicolumn{2}{|c|}{ Surface area, $\mathrm{cm}^{2}$} & 20 & 110.5 & 75.2 & 91.4 & 10.7 & 100 & 13.3 & 1.8 & 6.1 & 2.4 \\
\hline \multirow{2}{*}{ 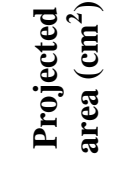 } & Major & \multirow{2}{*}{20} & 77.07 & 40.00 & 50.05 & 8.98 & 100 & 3.28 & 2.36 & 2.66 & 0.36 \\
\hline & Minor & & 50.50 & 35.70 & 42.27 & 4.40 & 100 & 0.60 & 0.32 & 0.50 & 0.14 \\
\hline \multicolumn{12}{|c|}{ Mechanical property } \\
\hline \multirow{2}{*}{ 氙 } & Empty & \multirow{2}{*}{50} & 28.5 & 25 & 27.5 & 1.01 & \multirow{2}{*}{100} & 39.5 & 34 & 36.5 & 1.2 \\
\hline & Filling & & 30.5 & 26 & 28.5 & 2.05 & & 41.0 & 36.5 & 38.7 & 1.12 \\
\hline \multirow{6}{*}{ 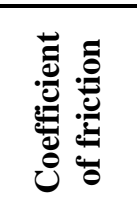 } & Wood & \multirow{6}{*}{20} & 0.61 & 0.20 & 0.30 & 0.10 & \multirow{6}{*}{20} & 0.69 & 0.35 & 0.3 & 0.14 \\
\hline & Glass & & 0.07 & 0.02 & 0.05 & 0.06 & & 0.21 & 0.10 & 0.15 & 0.02 \\
\hline & Rubber & & 0.5 & 0.20 & 0.30 & 0.09 & & 0.52 & 0.25 & 0.34 & 0.16 \\
\hline & Steel & & $\mathbf{0 . 3 3}$ & 0.12 & 0.20 & 0.08 & & 0.25 & 0.09 & 0.1 & 0.07 \\
\hline & Fiber & & 0.06 & 0.01 & 0.03 & 0.02 & & 0.12 & 0.08 & 0.1 & 0.03 \\
\hline & Plastic & & 0.15 & 0.07 & 0.09 & 0.01 & & 0.21 & 0.1 & 0.15 & 0.02 \\
\hline & & & & jing for & $(\mathbf{N})$ & & & & pture f & $(\mathbf{N})$ & \\
\hline & $\mathbf{L}$ & & 145 & 104 & 121 & 8.8 & & 63.6 & 25 & 35 & 12 \\
\hline & W & 20 & 127 & 94.5 & 102.2 & 7.8 & 20 & 143.4 & 95.6 & 126.6 & 14.2 \\
\hline & $\mathbf{T}$ & & 112.2 & 89.9 & 95 & 4.8 & & 135.4 & 103.6 & 122.2 & 13 \\
\hline
\end{tabular}


It was also noticed that angle of repose of clove for both methods was higher than for bulb. This is again because bulbs are viscous and the cohesion forces between clove and the wall are greater than cohesion between bulb. Knowing the angle of repose, determines the slope of the bottom of the tank which must be greater than its maximum value.

The rubbing force of bulb in the three major directions is presented in Table (1). It is noted that the rubbing force ranged from 89.9 to $145 \mathrm{~N}$. The rubbing force of bulb increased with $(\mathrm{L})>(\mathrm{W})>(\mathrm{T})$ direction. While the rupture force of the clove ranged from 35 to $135.4 \mathrm{~N}$. The rupture force of clove increased with $(\mathrm{W})>(\mathrm{T})>(\mathrm{L})$ direction. So that to design the rubbing machine, we take in consideration the force that required to rub the garlic bulb without damage of bulb ranging from 95 to $150 \mathrm{~N}$. Also, take in account the dimension of clove when design the rubbing machine to make the distance between the rollers is more than the dimension of clove, to avoid of rupture to the clove.

\section{CONCLUSION}

The obtained results can be summarized as follows:

1. The average values of physical properties measured at a moisture content of 12.97 (dry basis): for garlic bulb, length, width, thickness, mass, volume, solid density, bulk density, porosity, arithmetic mean diameter, geometric mean diameter, sphericity, packaging coefficient, surface area and projected area were $59.9 \mathrm{~mm}, 58 \mathrm{~mm}, 45.2 \mathrm{~mm}, 62.5$ $\mathrm{g}$, and $103.5 \mathrm{~cm}^{3}, 0.61 \mathrm{~g} / \mathrm{cm}^{3}, 0.45 \mathrm{~g} / \mathrm{cm}^{3}, 25.9 \%, 54.4 \mathrm{~mm}, 53.85$ $\mathrm{mm}, 0.90,0.97,91.4 \mathrm{~cm}^{2}$ and $(50.05 / 42.27) \mathrm{cm}^{2}$ respectively. For garlic clove values were $26.4 \mathrm{~mm}, 11.9 \mathrm{~mm}, 8.5 \mathrm{~mm}, 1.49 \mathrm{~g}$, and $4.39 \mathrm{~cm}^{3}, 0.94 \mathrm{~g} / \mathrm{cm}^{3}, 0.57 \mathrm{~g} / \mathrm{cm}^{3}, 39.6 \%, 15.6 \mathrm{~mm}, 13.7 \mathrm{~mm}, 0.53$, $0.46,6.1 \mathrm{~cm}^{2}$ and $(2.66 / 0.5) \mathrm{cm}^{2}$ respectively.

2. Coefficient of static friction of bulb and clove on various surfaces showed that static friction on rubber is higher then on other surfaces and static friction on fiber is the lowest.

3. Angles of repose of bulb and clove were higher when applying the filling method than when applying the empting method. It was also 
noticed that angle of repose of clove for both methods was higher than for bulb.

4. The rubbing force of bulb ranged from 95 to $145 \mathrm{~N}$. The rubbing force of bulb increased in (L), (W) and (T) directions.

5. The rupture of the clove ranged from 25 to $135.4 \mathrm{~N}$. The rupture forces of bulb increased in (T), (W) and (L) directions.

6. To design a rubbing machine, we take in consideration the force that required to rub the garlic bulb without damage of bulb or clove. The force required to rub bulb is more than $150 \mathrm{~N}$.

\section{REFERENCES}

Ahmad, J. I. 1996. Garlic-apanacea for health and good taste. Nutrition and Food Sc. 96(1): 32-35.

Altunta $^{\circ}$, E. ; E. Özgöz; and Ö.F. Taser. 2005. Some physical properties of fenugreek (Trigonella foenum-graceum L.) seeds. J. Food Eng., 71, 37-43.

ASAE. 1999. Moisture measurement - unground grain and seeds. ASAE S352.2 DEC97. In ASAE Standards 1999, 567. St. Joseph, MI: ASAE.

Bahnasawy, A. H. 2007. Some physical and mechanical properties of garlic. Int. J. Food Eng. 3, 1-18.

Chandrasekar,V. and R. Viswanathan. 1999.Physical and thermal properties of coffee. J. Agric. Eng. Res.73:227-234.

Gupta, R. K. and S. K. Das. 1997. Physical proerties of sunflower seeds. J. Agric. Eng. Res. 66:1-8.

Ibrahim M. M. 2008. Determination of dynamic coefficient of friction for some materials for feed pellet under different values of pressure and temperature. Misr J. Ag. Eng., 25(4):1389-1409.

Joshi, D.C.; S.K. Das; R.K. Mukherjee. 1993. Physical properties of pumpkin seeds. Agric. Eng. 54: 219-229. 
Kaleem, F.H.; Z.E. Ismail and G. R. AbdHakim.(1993).Factors affecting grain cleaning efficiency.(part 1): Grain straw mixture and blower characteristics.Misr J. Ag. Eng.10(2):369-382.

Karababa, E. 2006. Physical properties of popcorn kernels. J. Food Eng., 72, 100-107.

Konak, M.; K. Carman and C. Aydin. 2002. Physical properties of chick pea seeds. Biosys. Eng. 82(1): 73-78.

Madamba, P. S.; R. H. Driscoll and K. A. Buckle. 1993. Bulk density, porosity and resistance to airflow of garlic slices. Drying Tech. 11(7): 1837-1854.

Madamba, P. S.; R. H. Driscoll and K. A. Buckle. 1994. Shrinkage, density and porosity of garlic during drying. J. Food Eng. 23:309319.

Marijana, J. 1996. Effects of the size of planting material and soil preparation on the yield of garlic (ALLIUM SATIVUM L.). Res. Reports Biotec. Fac. Jamnikarjeva, Slovenia. Univ. Ljubljana. 67: 203-207.

Matlob, A. N. and A. M. Khalel. 1986. Effect of planting dates, plant spacing and clove size on vegetative growth and bulbing of garlic (ALLIUM SATIVUM L.). Iraqi J. Agric. Sc. zanco 4(3): 35-50.

Mohsenin, N. N. 1986. Physical Properties of Plant and Animal Materials, 2nd ed. Gordon and Breach Sc. Publishers

Nourai, A. H. 1994. Effect of planting methods and seed rates on yield, yield components and quality of garlic (ALLIUM SATIVUM L.) in the Sudan. Acta hort. 358: 359-364.

Olajide, J.O. and I. O. Ade-Omowaye. 1999. Some physical properties of locust beem seed. J.Agric. Eng. Res.74:213-215.

Olaniyan, A. and K. Oje. 2002. Some aspects of the mechanical properties of shea nut. Biosys. Eng. 4: 413-420.

Olaoye, J. O. 2000. Some physical properties of castor nut relevant to design of processing equipment. J. Agric. Eng. Res. 77(1): 113-118.

Schaper, A. L. and E.C. Yaeger. 1992. Coefficients of friction of Irish potatoes. Trans ASEA 35(5): 1647-1651. 
Schlumberger, S. 2008. Building a Hele-Shaw cell-experiment, http://www.seed.slb.com/en/scictr/lab/heleshaw/largecell.htm (accessed on 21 August 2008).

Song, H. and Litchfield, J. B. 1991. Predicting method of terminal velocity for grains. ASAS. 34 (1): 225 - 230.

Tabil, G. L.; H. Qi; K. K. Chawla; J. Kienholz; V. Crossman and R. White. 1999. Physical properties of selected special crops grown in Alberta. ASAE/CSAE annual international meeting. Paper No. 996049.

Topuz, A.; M. Topakci; M. Canakci; I. Akinci; and F., Ozdemir. 2005. Physical and nutritional properties of four orange varieties. J. Food Eng. Res., 66: 519-523.

Zhang, Q.; M. G. Britton and R. J. Kieper. 1994. Interactions between wheat and a corrugated steel surface. Trans. ASAE 37(3): 951-956.

الملخص العربي

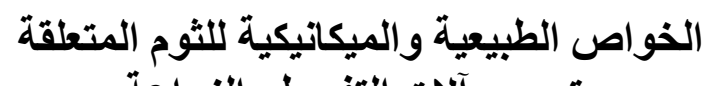
بتصميم آلات التفريط والزيكانيكة التوماعة

(1)

د. عبد الفتاح محمود محمد دريس (ل)

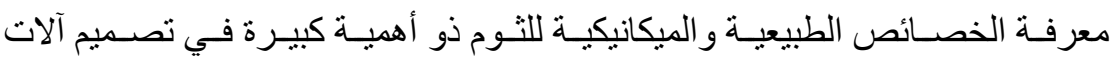

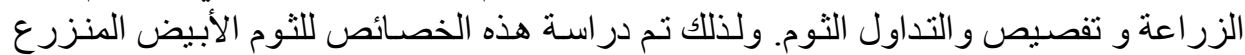
بمدينة البيضاء - ليبيا.

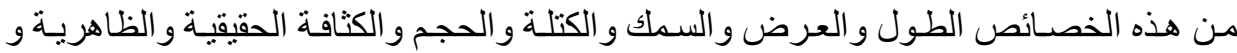

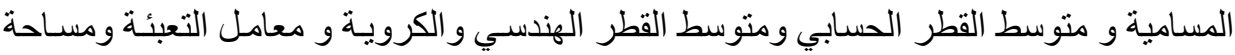

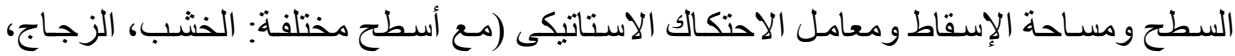

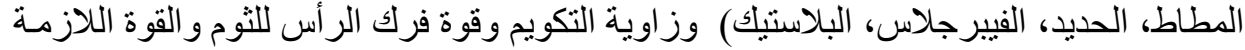
لكسر فصوص الكس الثوم.

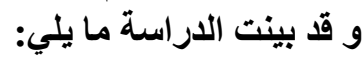

1 ـ متوسط قيم الخصائص الطبيعية والميكانيكية: (مع رؤوس الثوم)، الطول و العرض وض و السمك الكيك

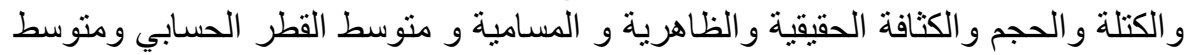

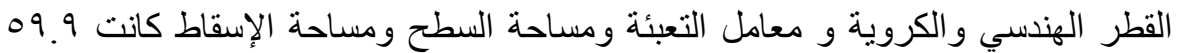

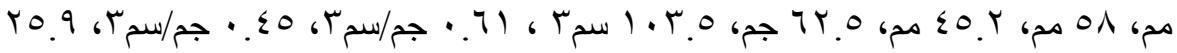

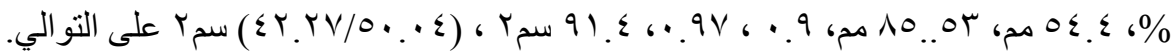
(1) مدرس الهندسة الزراعية_ كلية الزراعة ـ جامعة الأزهر- أسيوط. 


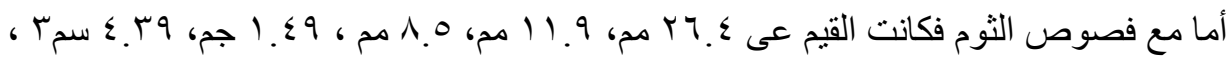
צ.

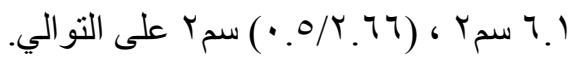

ץ- معامل الاحتكالك الاستاتيكى لرؤوس وفصوص الثوم مع مختلف الأسطح كانت عالية مع الأت المطاط عن الأسطح الباقية. بـ زاوية التكويم في حالة المله اكبر من الحالة الخاصة بالتفريغ، وكذللك زاوية التكويم مع

$$
\text { فصوص الثوم أكبر من الرؤوس. }
$$

$$
\text { ع - قوة تفريط رؤوس الثوم تثراوح من } 90 \text { إلى } 0 \text { ـ ا نيوتن. }
$$

هـ القوة اللازمة لكسر فصوص الثوم تتراوح من هץ إلى ع. هب ا نيوتن.

7- يمكن استخدام النتائج المتحصل عليها من الدراسة في تطوير آلات الزر اعة لمحصول الثوم

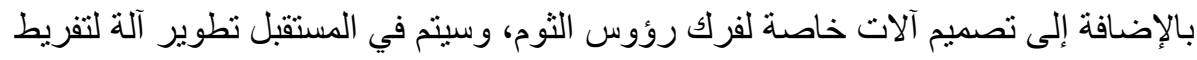

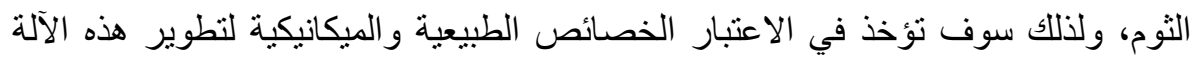
و اختيار المواد المناسبة للتصنيع. 